\title{
Источник субпикосекундных импульсов видимого спектрального диапазона на основе иттербиевого волоконного лазера с гибридной синхронизацией мод
}

\author{
И.В. Жлуктова ${ }^{*}$, В.А. Камынин, Н.Р. Арутюнян, А.С. Пожаров, \\ А.И. Трикшев, С.А. Филатова, Е.Д. Образцова, В.Б. Цветков \\ Институт общей физики им. А.М. Прохорова РАН \\ *E-mail: iv.zhluktova@gmail.com
}

DOI: 10.31868/RFL2020.89-90

Источники импульсного лазерного излучения видимого спектрального диапазона являются предметом исследования многих научных групп в мире. Интерес к ним обусловлен широким спектром реализованных и перспективных применений. В данный момент подобные лазерные системы используются для обработки различных материалов (стекло, некоторые виды полимеров и керамик, цветных металлов), а также как источники в астрономических адаптивных системах [1]. Особое место подобные источники занимают в перспективных медицинских системах диагностики и терапии как телеангиэктазии, так и офтальмологических патологий [2-4]. Основой для источников субнаносекундных импульсов видимого спектрального диапазона могут стать волоконные лазеры, работающие в режиме синхронизации мод в спектральном диапазоне 1 мкм.

В данной работе представлена оптическая система с использованием источника субпикосекундных импульсов для получения излучения видимого спектрального диапазона. Схема экспериментальной установки представлена на рисунке 1.

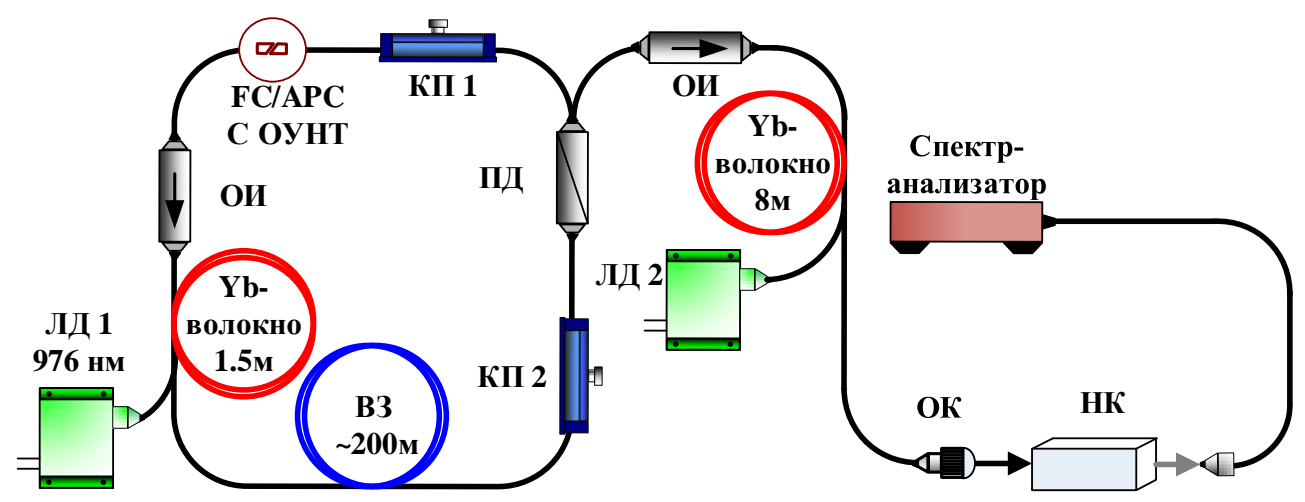

Рис. 1. Поэлементная схема экспериментальной установки: ВЗ- волокно задержки, ОИоптический изолятор, ПД- поляризационный делитель, ЛД 1,2- лазерный диод (мощность 0-8 Вт), КП 1,2- контроллер поляризации, НК- нелинейный кристалл, ОК- оптический коллиматор.

В качестве задающего источника использовался волоконный иттербиевый лазер, работающий в режиме гибридной синхронизации мод. В качестве активной среды задающего источника использовалось многокомпонентное волокно (GTWave). Общая длина резонатора задающего источника составляла более 200 м, что соответствует частоте следования импульсов 1 МГц. Длительность 
полученных импульсов составляла 200 пс. При использовании гибридного режима работы лазера, был обеспечен самозапуск и самоповторяемость режима работы задающего источника. Для реализации данного режима использовались одностенные углеродные нанотрубки в связи с эффектом нелинейного вращения эллипса поляризации. Для увеличения средней и пиковой мощности излучения использовался волоконный иттербиевый усилитель. Максимально усиленная средняя мощность составила более 600 мВт, что соответсвовало коэффициенту усиления 29 дБ. Пиковая мощность превышала значение 3кВт.

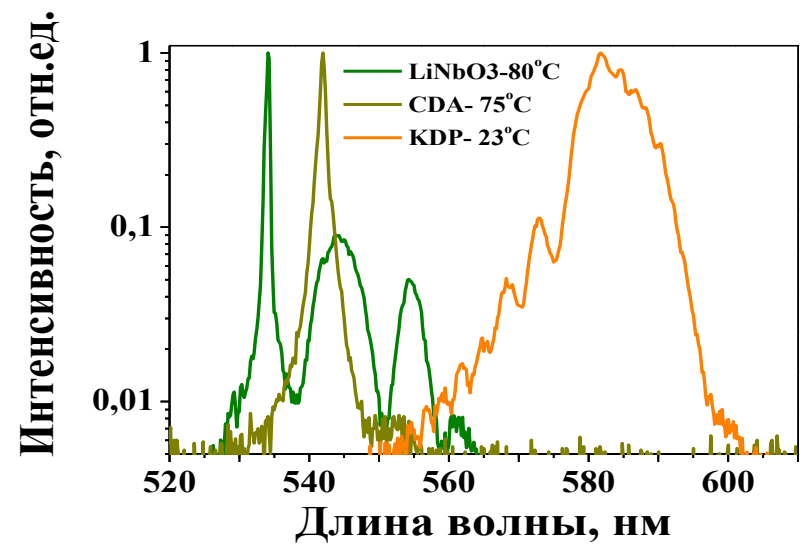

Рис.2. Полученные оптические спектры видимого спектрального диапазона.

После усилителя излучение фокусировалось при помощи оптического коллиматора в однопроходном генераторе второй гармоники (ГВГ). Для получения второй гармоники использовались три типа нелинейных кристаллов (HК): дигидрофосфат калия (KDP), ниобат лития $\left(\mathrm{LiNbO}_{3}\right)$, дигидроарсенат цезия (CDA). В зависимости от нелинейного кристалла, были получены оптические спектры в диапазоне от 530 нм до 580 нм. Средняя выходная мощность варьировалась от 300 мкВт (получено для CDA) до 1 мВт (при нагреве кристалла $\mathrm{LiNbO}_{3}$ ). Пиковая мощность оценивалась из параметров задающего источника и изменялась в пределах 1.5-5 Вт в зависимости от НК. Максимально полученная дифференциальная эффективность преобразования излучения составила $1.9 \%$ при использовании кристалла $\mathrm{LiNbO}_{3}$. В будущем, при модернизации ГВГ, появится возможность увеличения выходных параметров излучения видимого спектрального диапазона.

Исследование выполнено при финансовой поддержке РФФИ в рамках научного проекта № 19-32-90205.

\section{Литература}

[1] Y.Feng, L.R. Taylor, et al, Optics Express, 17, 19021 (2009)

[2] N.S. Sadick and R.Weiss., Dermatologic Surg. V. 28, 21-25 (2002)

[3] K. Inagaki, K. Ohkoshi., et al, Jpn. J. Ophthalmol. 59, 21 (2015)

[4] N. Yadav, C. Jayadev., et al, Eye 29, 258 (2015) 